\title{
Implementation of Technology-based Guided Inquiry to Improve TPACK among Prospective Biology Teachers
}

\section{Irdalisa}

Student of Post-Graduate Educational Sciences, Yogyakarta State University, Indonesia, irdalisa.ssi.2015@student.uny.ac.id

\section{Paidi}

Dr., Yogyakarta State University, Indonesia, paidi@uny.ac.id

\section{Djukri}

Prof., Yogyakarta State University, Indonesia,djukri@uny.ac.id

The prospective teachers can effectively master Technological Pedagogical and Content Knowledge (TPACK) through the application of technology-based guided inquiry as an effort to enhance technology literacy, learning quality and also as a medium for problem-solving. This study aimed at analyzing the impact on the implementation of technology-based guided inquiry to improve students' TPACK ability. This study employed a one-group pretest-posttest design. The research population was the students of Biology Education Department, Syiah Kuala University, Indonesia. The research sample was 47 students taken with purposive sampling technique. The research instruments employed a test and a questionnaire. The data were analyzed using a paired sample t-test and quantitative descriptive. The results showed that students' understanding of TPACK according to all assessment aspects can be categorized as "very good". In details, the content knowledge had a higher posttest score than the pretest. Therefore, it can be concluded that the application of technology-based guided inquiry has a significant impact to improve the students' understanding of TPACK including Content Knowledge (CK), Pedagogical Knowledge (PK) and Technological Knowledge (TK). The application of guided inquiry learning on TPACK can restructure teachers' experience for their professional development by designing their own learning materials with technology use.

Keywords: guided inquiry, content knowledge, pedagogical knowledge, technological knowledge, prospective teacher

Citation: Irdalisa, Paidi, \& Djukri. (2020). Implementation of Technology-based Guided Inquiry to Improve TPACK among Prospective Biology Teachers. International Journal of Instruction, 13(2), 33-44. https://doi.org/10.29333/iji.2020.1323a 


\section{INTRODUCTION}

The use of technology in learning process has become the main concern for all educational components (Jimoyiannis, 2010) which is considered as crucial factor to improve the quality of education. According to Meenakshi (2013), the goals of technology in education are to improve technological literacy among students, to enhance the learning quality, and to promote problem-solving activities. The prospective teachers require to master Technological Pedagogical and Content Knowledge (TPACK), namely technological knowledge, pedagogy and field of expertise so that they can easily create their own learning tools, materials, and media with the current technology.

The development of Information and Communication Technology (ICT) in education can be seen from the use of computers in creating practical, interesting and interactive learning media. The concepts, methods, and applications of ICT keep growing and it has been applied contextually. The use of ICT in education also supports student-centered learning (Alemu, 2015). To respond to ICT development, lecturers and students should grasp technology by developing ICT-based learning and utilizing ICT as an effective and efficient learning medium.

Based on the pre-survey results, there were a few meaningful integrations between ICT and learning that cause most of the students seem to lack knowledge of TPACK, especially in Biology learning. It has pleaded the development of ICT-assisted Inquiry models. This model is a framework that represents the existence and the specifications of various technologies and other supporting applications in order to build new learning interactions by focusing on activities and providing direct learning experiences to emphasize students' involvement in problem-solving.

It appears that the students find it difficult to understand Content Knowledge (CK), Pedagogical Knowledge (PK), Technological Knowledge (TK), and learning integration, especially in Biology field since their learning process has not been oriented to TPACK. It can be caused by the absence of a Biology learning model, particularly in the Anatomy of Human Physiology subjects, that implements the guided Inquiry integrated with ICT which is based on the students' characteristics, potential, and learning styles. In fact, problem-solving activities and concepts formulation through integrated activities play a crucial role in the learning process (Suyanto \& Asep, 2013). Inquiry learning can train students in problem-solving, problems identification, as well as skills development to solve encountered difficulties. In line with this, Bugarcic et al., (2012) state that Inquiry-based learning can assist students to obtain benefits from the process of scientific inquiry, unfortunately, they are lack of experience and basic knowledge of science content where those should be considered first before the students conducting their research. In this case, the use of information technology can accelerate innovation of learning resources and media.

These findings are relevant to similar research findings that are to achieve a useful integration between multimedia and learning activities, teachers must be trained that not only focuses on the technical issues but also addresses pedagogies to integrate 
technological awareness and proper teaching strategy (Webb, 2010; Rogers \& Twidle, 2011). Ferreira, C, Baptista, M \& Arroio, A. (2013) emphasize that the use of pedagogical knowledge for specific learning and teaching environments can occur in ICT-based inquiry learning to support innovative teaching.

Sen and Gulsah (2016) note that inquiry is a teaching strategy that aims at developing students' abilities to deal with problems they may encounter. Amy, at al., (2013) and Yanto, at al., (2019) also clarify that, in inquiry-based learning, students can work in groups to explore problems and solve questions through scientific investigation. The purpose of applying inquiry learning strategy is to develop the ability to think systematically, logically, and critically, as well as to enhance intellectual abilities as part of mental processes.

This study used guided Inquiry as a learning process where the lecturers provide extensive guidance, and determine the given problems to students in the form of questions and statements in the worksheets. Those are clearly written in case of the information discovery or the obtained data. The guided inquiry is effective to encourage the students' involvement and motivation and help them to gain deeper understanding of learning. This research is expected to realize the process of effective guided inquiry learning in order to expand students' understanding of Content Knowledge (CK), Pedagogical Knowledge (PK), Technological Knowledge (TK). The framework of this study is presented in Figure 1 below.

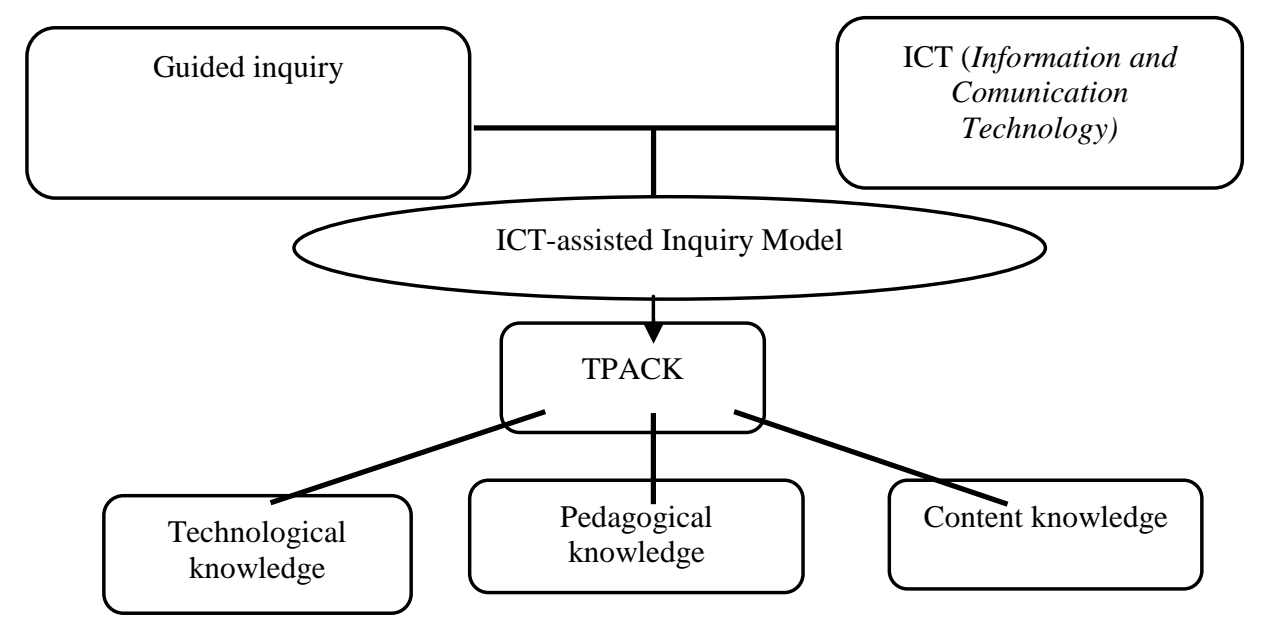

Figure 1

The Scheme of ICT-Assisted Inquiry Model

The aspects formulation of the students' understanding on TPACK consisting of Content Knowledge (CK), Pedagogical Knowledge (PK), Technological Knowledge (TK), in this study, as presented in Table 1 below. 
Table 1

The Aspects of Pedagogical Knowledge (PK), Technological Knowledge (TK) and Content Knowledge (CK)

\begin{tabular}{ll}
\hline Aspects & Indicators \\
\hline Pedagogical & The completeness of syllabus elements \\
(PK) & The appropriateness between indicators and learning outcomes \\
& The formulation of learning experience (based on learning model) \\
& The activities quality which is guided in indicators \\
& The appropriateness between assessment and indicators \\
& The component and Lesson Plan identity \\
& The purpose formulation \\
& The appropriateness between Lesson Plans and learning resources \\
& The appropriateness between learning activities and method characteristics \\
& The urgency, relevance, and use of media or technology \\
\hline Technological & The illustration on media or technology to supports materials \\
Knowledge & The use of communicative language in materials \\
(TK) & The support of media to engage students with technology \\
& The proportional use of text, graphics, and animation \\
& The use of visualization to assist students' understanding of the learning \\
& concepts \\
& The feasibility of media on the teaching materials \\
\hline Content & The knowledge on the subject matter \\
Knowledge & The explanation of abstract materials \\
(CK) & The use of material analogies and concrete examples \\
& The material presentation \\
\hline
\end{tabular}

Through ICT-assisted Inquiry model, the students are expected to be able to improve their TPACK ability of which they can create their own learning media combined with technology. In addition, as teachers, they demand to understand not only the teaching material but also the way to make their students understand and to apply these concepts with the technology application (Mishra \& Mattew, 2006). Considering the background above, the research question can be formulated as, "How is the effectiveness of ICTassisted Inquiry model to improve TPACK ability among the students of Biology Education in Syiah Kuala University?"

\section{METHOD}

\section{Research Design}

This study used a one-group pretest-posttest design to determine the escalation of students' content knowledge, and a quantitative approach was for pedagogical and technological knowledge. The research population was the students of Biology Education Department of Syiah Kuala University, Indonesia in the academic year of $2017 / 2018$.

The research sample consisted of 47 students in one experimental class through purposive sampling technique. One class as an experimental class applied guided inquiry for once a week with 120 minutes. This research was conducted for three months starting from May until June 2018. The guided inquiry steps covered the explanation of 
learning procedures, the problems presentation, the data collection, and the hypothesis testing. The further explanation is presented in Table 2 below.

Table 2

The Stages of Guided Inquiry Learning

\begin{tabular}{ll}
\hline Steps & Teachers and students activities \\
\hline $\begin{array}{l}\text { The explanation of } \\
\text { learning procedures }\end{array}$ & $\begin{array}{l}\text { The lecturer explained the purpose and of learning steps with the } \\
\text { assistance of Prezi, ppt and learning video applications. } \\
\text { The students paid attention to lecturers' explanations of learning } \\
\text { procedures }\end{array}$ \\
\hline $\begin{array}{l}\text { The presentation of } \\
\text { problems }\end{array}$ & $\begin{array}{l}\text { The lecturer presented the problem which was stated in the form of } \\
\text { questions } \\
\text { The students looked for problems in their surrounding } \\
\text { environment as material for discussion and tried to find solutions } \\
\text { in their group members }\end{array}$ \\
\hline $\begin{array}{l}\text { The data collection and } \\
\text { hypothesis testing }\end{array}$ & $\begin{array}{l}\text { The lecturer guided the students in data collection and hypothesis } \\
\text { testing activities }\end{array}$ \\
& $\begin{array}{l}\text { The students were asked to identify information from various } \\
\text { learning sources }\end{array}$ \\
\hline The formulation of & $\begin{array}{l}\text { The lecturers provide feedback on ongoing learning activities } \\
\text { explanations and } \\
\text { The students formulated the results of hypothesis testing } \\
\text { The lecturer guided students in formulating conclusions on } \\
\text { learning outcomes } \\
\text { The students drew their own conclusions }\end{array}$ \\
\hline
\end{tabular}

\section{Data Collection and Analysis}

The data were collected in the form of test scores and questionnaires responses. The assessment on students' test instrument was to find out students' Knowledge Content, while the questionnaires were to measure PK and TK. There were 3 meetings for the implementation of inquiry learning with 20 items consisting of CK, PK and TK instruments. These had been made by the researchers and validated by four educational experts. The validity testing was used to determine the validity of the instrument items where all instruments were declared valid $(\mathrm{p}<.05)$. The instrument validity was done by examining the expert agreement based on Aiken (V) index. The results of these measurements are presented in Table 3

Table 3

The Results of Aiken Index Coefficient for Learning Instrument Validity

\begin{tabular}{lll}
\hline \multicolumn{1}{c}{ Instrument } & V & Explanation \\
\hline Content Knowledge (CK) & .78 & Valid \\
\hline Pedagogical Knowledge (PK) & .77 & Valid \\
\hline Technological Knowledge (TK) & .76 & Valid \\
\hline
\end{tabular}

The Cronbach's alpha coefficient from the CK test was .962, TK questionnaire was .975 and PK was .910. It indicates the reliability score is in the high category (Sarwono, 2015). The instruments guidelines, indicators of CK, PK and TK are presented in Table 4 as follows. 
Table 4

The Instruments Guidelines of Pedagogical Knowledge (PK), Technological Knowledge (TK) and Content Knowledge (CK)

\begin{tabular}{|c|c|c|}
\hline Aspects & Indicators & No item \\
\hline Pedagogical & The completeness of syllabus elements & 1 \\
\hline \multirow[t]{8}{*}{ knowledge (PK) } & $\begin{array}{l}\text { The appropriateness between indicators and learning } \\
\text { outcomes }\end{array}$ & 1 \\
\hline & $\begin{array}{l}\text { The formulation of learning experience (based on } \\
\text { learning model) }\end{array}$ & 1 \\
\hline & The activities quality which is guided in indicators & 1 \\
\hline & The appropriateness between assessment and indicators & 1 \\
\hline & The component and Lesson Plan identity & 1 \\
\hline & The purpose formulation & 1 \\
\hline & $\begin{array}{l}\text { The appropriateness between Lesson Plans and learning } \\
\text { resources }\end{array}$ & 1 \\
\hline & $\begin{array}{l}\text { The appropriateness between learning activities and } \\
\text { method characteristics }\end{array}$ & 1 \\
\hline Technological & The urgency, relevance and use of media or technology & 1 \\
\hline \multirow[t]{6}{*}{ knowledge (TK) } & $\begin{array}{l}\text { The illustration on media or technology to supports } \\
\text { materials }\end{array}$ & 1 \\
\hline & The use of communicative language in materials & 1 \\
\hline & The support of media to engage students with technology & 1 \\
\hline & The proportional use of text, graphics, and animation & 1 \\
\hline & $\begin{array}{l}\text { The use of visualization to assist students' understanding } \\
\text { of the learning concept }\end{array}$ & 1 \\
\hline & The feasibility of media on the teaching materials & 1 \\
\hline Content & The knowledge on the subject matter & 1 \\
\hline \multirow[t]{3}{*}{ knowledge (CK) } & The explanation of abstract materials & 1 \\
\hline & The use of material analogies and concrete examples & 1 \\
\hline & The material presentation & 1 \\
\hline
\end{tabular}

The data were analyzed using t-test to know the significant test between the pretest and posttest data. Meanwhile, the prerequisite test was done by determining normality and homogeneity data.

\section{FINDINGS}

\section{Assessment Data on Students' Technological Knowledge}

Based on the analysis results, the obtained data for the students' Technological Knowledge are shown in Figure 2. It covered the percentage of technological knowledge, cognitive content, integration, aesthetics, and overall function. 


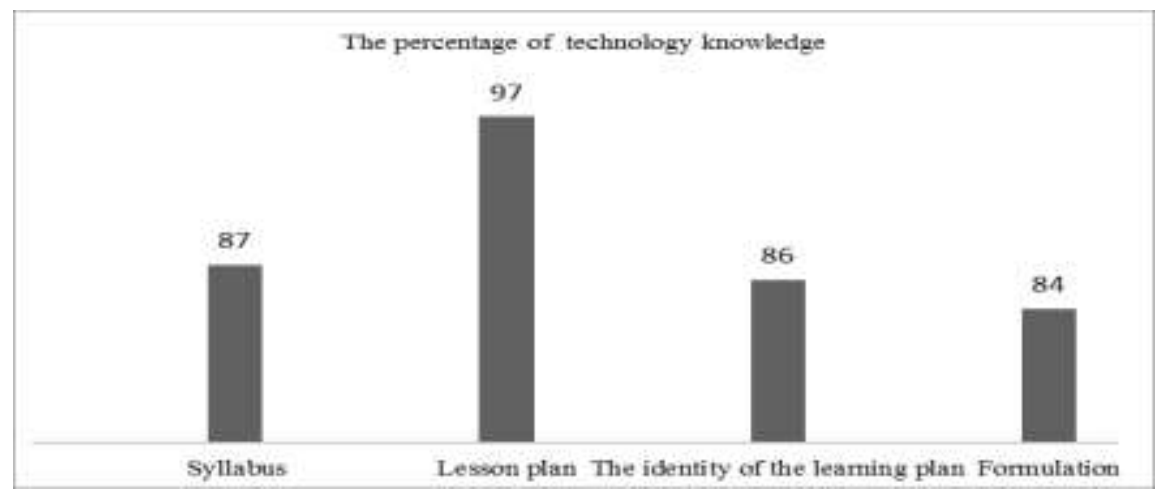

Figure 2

The Percentage of the Students' Technological Knowledge

Based on the picture above, the cognitive aspects of the designed learning media had the lowest score of 88 , while the aspects of media integrity and overall functions obtained the highest score of 100. The data shows that the students' Technological Knowledge can be categorized as "very good".

\section{Assessment Data on Students' Pedagogical Knowledge}

Based on the analysis results, the obtained data on student pedagogical knowledge from all aspects of assessment were in "very good" category as shown in Figure 3.

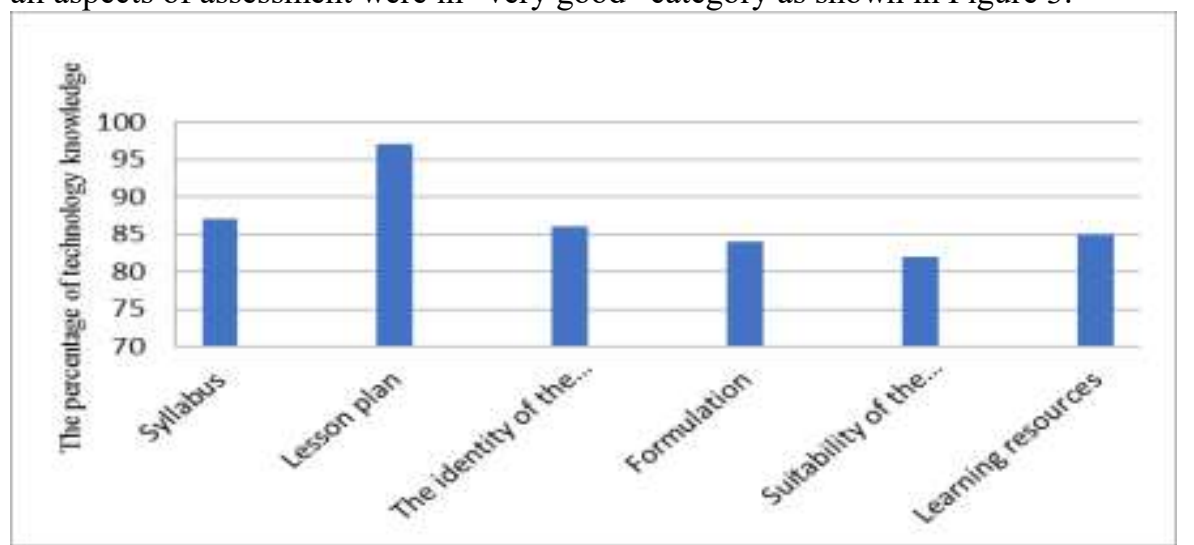

Figure 3

Percentage of the Students' Pedagogical Knowledge

\section{Assessment Data on Students' Content Knowledge}

The students' content knowledge is related to students' understanding of material concepts. It was analyzed before and after the application of the Inquiry model. The test scores from content knowledge showed that after the implementation of guided inquiry, the post-test score was higher than the pretest score with 57.5 for pre-test and 86.9 for post-test (Table 5). 
Table 5

The Results of the Content Knowledge Test (Pre-Test and Post-Test)

\begin{tabular}{lccccc}
\hline Model & $\mathrm{N}$ & Pretest & \multicolumn{3}{c}{ Posttest } \\
\cline { 2 - 6 } & & Mean & Std. Error & Mean & Std.Error \\
\hline Guided inquiry & 47 & 57.5 & 4.96 & 86.9 & 5.39 \\
\hline
\end{tabular}

Based on the Kolmogorov-Smirnov One-Sample test, pre-test (5.99) and post-test (7.47) both had significant values $(p>.05)$. It means that the scores from both tests were normally distributed. Based on the homogeneity test and Levene test, the significant value was 1.18 meaning that the scores of tests had homogeneous variance $(p>.05)$. The result of normality and homogeneity test had fulfilled the parametric test assumption, which required the normally distributed data and it had homogeneous variance prior to the t-test.

Table 6

T-Test Summary

\begin{tabular}{lll}
\hline Experiment class & $\mathrm{T}_{\text {count }}$ & Asymp. Sig. (2-Tailed) \\
\hline Posttest- Pretest & 41.77 & .000 \\
\hline
\end{tabular}

The result of Table 6 showed that the inquiry model had different mean score significantly. The results of this research indicate that there is an effect on the inquiry model implementation towards the improvement of students' content knowledge $(\mathrm{t}=$ 41.77, $\mathrm{p}=.000<.05)$.

\section{DISCUSSION}

Based on the research findings, the implementation of the inquiry model can enhance the students' understanding of Technological Knowledge with "very good" category because the teachers already have the awareness and skills to apply ICT in learning. It is supported by Ertmer et al., (2012) on the importance of teachers to have an awareness in developing ICT-based learning through innovative and creative learning approaches. Technology Knowledge as knowledge about technology for teaching and learning (Suryawati et al., 2014). Technology continues to develop that make technology keep shifting from time to time (Mishra \& Mattew, 2006). Therefore, the ability to learn and adapt new technologies is very important and it includes an understanding of how to use computer software and hardware, presentation tools such as document presenters and worksheets, and other technologies in the educational context. It also involves the ability to adapt and learn new technologies (Koehler et al., 2013). In addition, the benefits of ICT can be a motivating factor for students to be active in learning (Howard et al., 2015; Petko, 2012). According to Tsai \& Chai (2012), teachers who are able to design ICTbased learning beneficially impact on students in constructing their knowledge to have meaningful learning experiences.

Moreover, the escalation of the value in the post-test on the aspect of content knowledge (CK) was due to the application of the guided inquiry model which was supported by several research results that applied technology-based inquiry including Nirwana (2013) on the use of ICT-based Inquiry models. The results of Nirwana's study conclude that the use of ICT-based Inquiry models can improve student learning processes and 
outcomes. Another study by Ching, Joyce \& Chin (2013) showed positive results in the development of teachers' ability to integrate ICT into instructional practice.

The results of data analysis on the students' pedagogical knowledge in all aspects of assessments were in "very good" category. According to Mar'atus et al., (2016) the guidance process in mastering TPACK plays an important role and a strong influence on the ability to create learning tools and other supporting aspects. These results were supported by Rani, Baskoro, \& Dewi (2016), Mahdum (2015), Suryawati, Firdaus \& Joshua (2014).

TPACK development is used to provide learning experiences that are adapted to specific pedagogies for specific materials (Koehler et al., 2013). This is supported by Aquino (2015) where the development of TPACK is important for novice teachers to create effective learning process. Teachers must choose teaching approaches and learning models that are appropriate to the learning content and the possible technology application. The proper teaching with technology cannot be achieved by just adding new parts of technology to the existing structures since the technology-based teaching stimulates a shift in the pedagogical domain and the existing content. The use of educational technology is required to support Inquiry learning, learning content, pedagogy, and technology awareness and interactive interactions for the successful integration between technology and science learning (Srisawasdi, 2014).

TPACK is knowledge about particular topics in certain domains by using specific technology and appropriate pedagogical approach (Hashim et al., 2013). Therefore, the mastery of TPACK plays an important role in preparing and developing the teaching competency of prospective teachers. It underlines the importance of the teacher's ability to integrate technology in the learning process with appropriate pedagogical methods and technologies (Schmidt et. al., 2009). Serious attention to TPACK can restructure professional development among teachers in designing learning technologies. TPACK trains tutors, teachers, and educational researchers (Mishra \& Mattew, 2006).

Teachers with adequate TPACK's ability can provide new directions in solving problems related to the use of ICT during the classroom learning process (Chai et al., 2011). The research on teacher education reports that TPACK model can be used as a framework to prepare and develop teacher teaching competency. It is a strong foundation that has many generative potentials in research and development related to the use of ICT in education. Hashim et al., (2013) states that the use of technology in teaching can influence the concepts understanding so that teachers must properly choose the teaching approach to the learning content of the subject matter and the technology that they want to be implemented. The ability to learn and adapt to new technologies is very important to be used for various pedagogical tasks, such as research and communication (Mishra \& Mattew, 2006; Koehler et al., 2013).

Teachers with deep pedagogical knowledge understand how to build students' knowledge, acquire skills, and develop positive thinking skills towards learning. Thus, pedagogical knowledge requires an understanding of cognitive, social, and learning theories as well as its application in the classroom (Schmidt, 2009). Teachers with lack of materials understanding can incorrectly represent the material to their students. 
Suryawati et al., (2014) state that Content Knowledge is about concepts, theories, ideas, frameworks, proofing knowledge, practices and approaches for knowledge development. It means the teacher must master their teaching material broadly and deeply. The knowledge content is important because it determines specific methods for each field (Koehler et al., 2013). The current developments have put pressure on academic institutions to improve the curriculum and make it relevant to the current needs. There is an urgent and persistent need to integrate technology into the learning process. Digital and non-digital technology can be used to support every type of learning activity (Harris et al., 2009). Technology can help students and prospective teachers in their professional development to obtain the latest issues regarding education, learning strategies and the development of science in accordance with their fields of expertise.

\section{CONCLUSION AND IMPLICATION}

Based on the research findings, it can be concluded that the application of technologybased guided inquiry beneficially impacts on the escalation of the students' technological and pedagogical knowledge aspects in all assessment aspects that were in "very good" category. In addition, there was a significant development in the scores of posttest on the aspects of content knowledge (CK) since the teachers already have the awareness and skills of ICT application in guided inquiry learning. TPACK development is used to provide the students with the learning experiences which is adapted from specific pedagogy and made for specific content. Based on the research findings, some suggestions can be proposed. For the teaching contexts, it varies greatly between technology, pedagogy, and content so that lecturers must be able to make decisions in line with the current developments of technology, pedagogy, subject matter, and classroom context. In terms of teaching, teachers can use the suitable technology related to the three aspects of knowledge namely technology, pedagogy, as well as content and interaction among the aspects of knowledge. In the technology use, it should be presented with new concepts by promoting the development of sensitivity to causally relevant dynamic information as well as the relationship among those three components. Moreover, this study suggests the urgency among lecturers to integrate technology in their teaching and learning process by employing some approaches to nurture Technological Knowledge (TK) in order to enhance technological literacy among prospective teachers. The implication of guided inquiry learning on TPACK can restructure teachers' experience for their professional development by designing their own learning materials with the technology application.

\section{REFERENCES}

Alemu, B. M. (2015). Integrating ICT into teaching-learning practices: promise, challenges and future directions of higher educational institutes. Universal Journal of Educational Research, 3(3), 170-189.

Amy R. P., Amanda L. S., Malathi, S., Christopher W. B., Lawrence S. B., \& Anne A. G. (2013). Inquiry-based investigation in biology laboratories: does neem provide bioprotection against bean beetles? Bioscene, 38(2).

Aquino, A. B. (2015). Self-efficacy on technological, pedagogical and content 
knowledge (TPACK) of biological science pre-service teachers. Asia Pacific Journal of Multidiciplinary Research, 3(4),150-157.

Bugarcic, A., Zimbardi, K., Macaranas, J., \& Thorn, P. (2012). An inquiry-based practical for a large, foundation-level undergraduate laboratory that enhances student understanding of basic cellular concepts and scientific experimental design. The International Union of Biochemistry and Molecular Biology, 40(3), 174-180

Chai, C.S., Koh, J.H.L., \& Tsai, C.C. (2013) A review of technological pedagogical content knowledge. Educational Technology and Society, 16(2), 31-51.

Ertmer, P. A., Ottenbreit-Leftwich, A. T., Sadik, O., Sendurer, E., \& Sendurer, P. (2012). Teacher beliefs and technology integration practices: A critical relationship. Computers \& Education, 59(2), 423-435.

Ferreira, C, Baptista, M., \& Arroio, A. (2013). Teachers' pedagogical strategies for integrating multimedia tools in Science Teaching. J. of Baltic Sci. Edu, 12(4), 509-524.

Harris, J., Punya M., \& Matthew K. (2009). Teachers' technological pedagogical content knowledge and learning activity types: curriculum-based technology integration reframed. Journal of Research on Technology in Education, 41(4), 393-416.

Hashim, Zulkefli., \& Fatin, A. P. (2013). Amalan pengetahuan teknologi pedagogi kandungan guru fizik tingkatan enam. Int. Sem. on Qua. and Affordable Edu. (ISQAE).

Howard, S. K., Chan, A., \& Caputi, P. (2015). More than beliefs: Subject areas and teachers' integration of laptops in secondary teaching. B. J. of Edu Tec. 46(2), 360-369.

Jimoyiannis, A. (2010). Developing a technological pedagogical content knowledge framework for science education: implications of a teacher trainers' preparation program. Proce of Information Science \& IT Education Conference (InSITE), 597-607.

Koehler, M. J., Mishra, P., Akcaoglu, M., \& Rosenberg, J.M. (2013). The technological pedagogical content knowledge framework for teachers and teacher educators. In ICT integrated teacher education models (pp. 1-8). New Delhi, India: Commonwealth Educational Media Center for Asia.

Mahdum. (2015). Technological pedagogical and content knowledge (TPACK) of English teacher in Pekanbaru, Riau, Indonesia. Mediterranean J. of Soc. Sci, 6(5).

Mar'atus, S., Lia, Y., \& Wartono. (2016). Peranan tpack terhadap kemampuan menyusun perangkat pembelajaran calon guru fisika dalam pembelajaran post-pack. Jurnal Pendidikan, 1(2), 144-153.

Meenakshi. (2013). Importance of ICT in education. Journal of Research \& Method in Education (IOSR-JRME), 1(4), 2320-73788.

Mishra, P., \& Mattew J. K. (2006). Technological pedagogical content knowledge: A framework for teacher knowledge. Teachers College Record, 108(6), 1017-1054. 
Nirwana. (2013). Penggunaan model inquiry berbasis ict untuk meningkatkan hasil belajar pada mata kuliah sejarah fisika mahasiswa prodi pendidikan fisika jurusan pendidikan mipa fkip univeristas bengkulu. Prosiding Semirata FMIPA U. Lampung.

Petko, D. (2012). Teachers' pedagogical beliefs and their use of digital media in classrooms: Sharpening the focus of the 'will, skill, tool' model and integrating teachers' constructivist orientations. Computers \& Education, 58 (4), 1351-1359

Rani. P., Baskoro, A.P., \& Dewi. P.S. (2016). Penerapan model pembelajaran inkuiri terbimbing pada materi sistem ekskresi kulit untuk meningkatkan keterampilan proses sains siswa kelas XI SMA. Proceeding Biology Education, 13(1) 2016: 325-329.

Rogers, L., \& Twidle, J. (2011). A pedagogy for teaching science with ICT. Paper presented at 9th International Conference ESERA. Lyon, France.

Sen, C., \& Gulsah S. V. (2016). The impact of inquiry-based instruction on science process skills and self-efficacy perceptions of pre-service science teachers at a university-level biology laboratory. Universal J. of Edu. Research, 4(3), 603-612.

Schmidt, D. A., Evrim B., Ann D., Punya M, Matthew J. K., \& Tae S. Shin. (2009). Technological pedagogical content knowledge (TPACK): The development and validation of an assessment instrument for preservice teachers. Journal of Research on Technology in Education. 42(2) 123-149.

Srisawasdi, N. (2014). Developing technological pedagogical content knowledge in using computerized science laboratory environment: an arrangement for science teacher educational program. Res. and Prac. in Tech. Enhanced Learning, 9(1), 123-143.

Suryawati, E., Firdaus L.N., \& Yosua H. (2014). Analisis keterampilan technologica pedagogical content knowledge (TPACK) guru biologi sma negeri kota pekanbaru. Jurnal Biogenesis, 11(1), 67-72.

Suyanto., \& Asep, J. (2013). Menjadi guru profesional; Strategi meningkatkan kualifikasi dan kualitas guru di era global. Jakarta: Erlangga

Tsai, C.-C., \& Chai, C. S. (2012). The "third"-order barrier for technology integration instruction: Implications for teacher education. In C. P. Lim, \& C. S. Chai (Eds.), Building the ICT capacity of the next generation of teachers in Asia. Australasian Journal of Educational Technology, 28(6), 1057-1060.

Webb, M. E. (2010). Technology-mediated learning. In J. Osborne, \& J. Dillon (Eds.), good practice in science teaching-what research as to say? (pp. 158-182). Maidenhead: Open University Press.

Yanto, B. E., Subali, B., \& Suyanto, S. (2019). Measurement instrument of scientific reasoning test for biology education students. Int. J. of Instruction, 12(1), 1383- 1398. 